\title{
Efficacy of Platelet Rich Plasma in the Treatment of lipoatrophy
}

\author{
Zerrin Ogretmen ${ }^{1 *}$ and Yankı Büke Otles ${ }^{2}$ \\ ${ }^{1}$ Department of Dermatology, Canakkale Onsekiz Mart University, Turkey \\ ${ }^{2}$ Atatürk Education and Research Hospital, Turkey
}

Submission: July 13, 2017; Published: August 10, 2017

*Corresponding author: Zerrin Ogretmen, Department of Dermatology, Çanakkale Onsekiz Mart University, Çanakkale, Turkey,

Email: zogretmen@gmail.com

Keywords: PRP; Lipoatrophy; Localized involutional lipoatrophy

\section{Introduction and Objectives}

Localized involutional lipoatrophy (LIL) is a rare a symptomatic, idiopatic form of localized lipoatrophy seen in dermatological practice. LIL usually presents as a solitary, localized, well demarcated, fresh colored, asymptomatic, atrophic depression. It frequently, develops on the injection areas [1,2].

Platelet-rich plasma (PRP) is highly concentrated auto logous solution of plasma prepared from a patient's own blood. PRP contains platelets that are purported to release numerous growth factors that may be valuable in numerous dermatologic applications. We know the addition of platelets and their associated growth factors opened new possibilities, for the treatment of chronic skin ulcers. Therefore the application of PRP; for lipoatrophy treatment is a new treatment [3-6].

Material and Methods

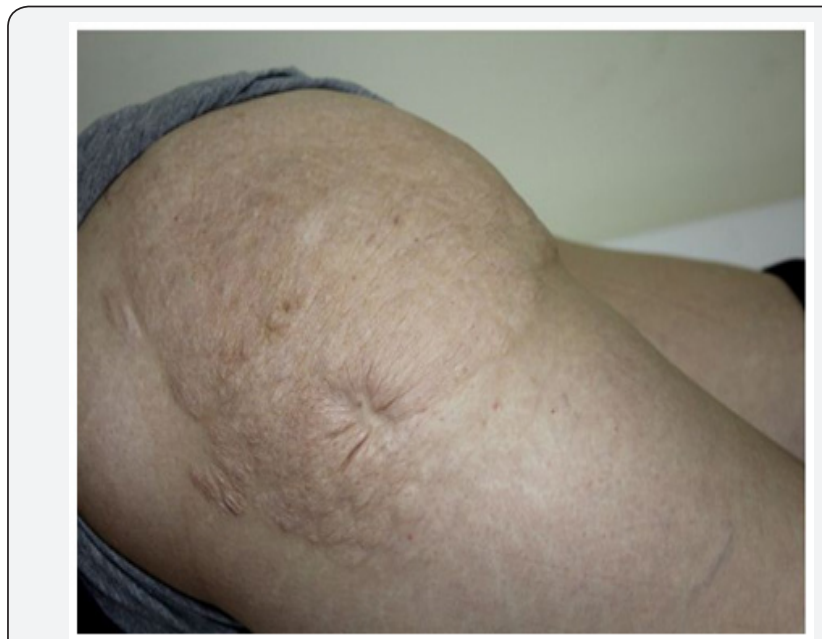

Figure 1: Case. 18-year old female patient was admitted to our outpatient clinic with thinning and disfigurement complaint of her skin on her hip (Figure 1).

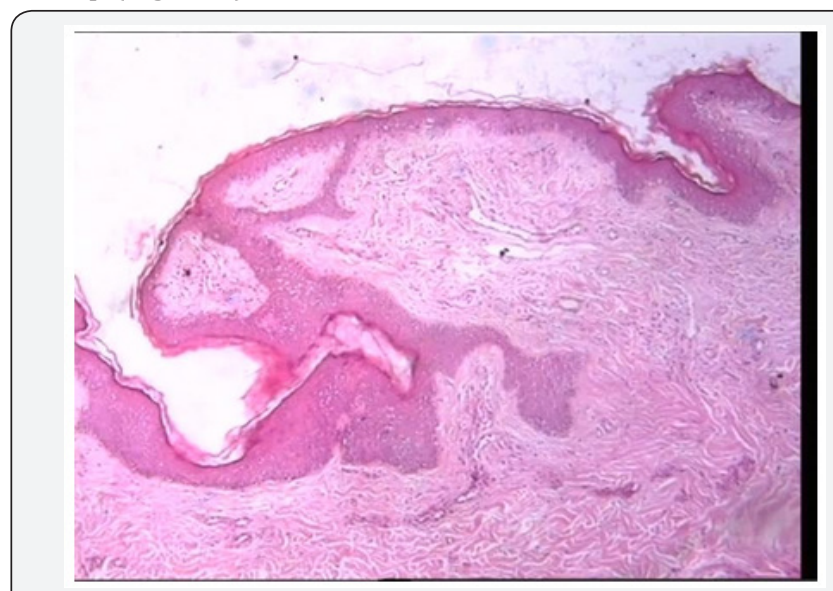

Figure 2: (HE X40) Fatlobules composed of numerouss malllipocytes in thehyaline connective tissue. (bevor treatment).

She said that her problem started when she was a month old baby. The lesion was $0.5 \mathrm{~cm}$ in diameter and increased overtime. By dermatological examination; $25 \mathrm{~cm}$ diameter, sharply demarcated, skin color, depressed, a trophic plaques were observed on left gluteal area. She had no history of any injury or injection or operation at the site. Skin biopsy was consistent with the results of lipoatrophy (Figure 2).

PRP is prepared in various forms. Pure PRP is the most commonly used form consisting of a buffy coat with a large number of platelets with little leukocytes being collected. PRP contains various growth factors contained in alpha granules and dense granules. Alpha granules contain seven fundamental 
growth factors: the platelet derived growth factors (PDGFaa, PDGFbb, and PDGFab), transforming growth factor beta (TGF $\beta 1$ and 2), epithelial growth factor (EGF), and vascular endothelial growth factor (VEGF) [4].

In recent years PRP is frequently used in cosmetic dermatology. Good outcomes for other dermatological indications such as skin ulcers and alopecia have been reported in studies [6]. It is used more often in procedures such as fat grafting or soft tissue augmentation due to the slower secretion over a longer time period [7].

\section{Results}

Localized involutional lipoatrophy (LIL) is a rare a symptomatic, idiopathic form of localized lipoatrophy. Most of the patients are women. Lesion is frequently solitary. Mostly buttocks and proximal extremities are affected. Our patients also had the same properties. Laboratory examination showed normal findings; except Total IgE: 294U/ml (normal: 0-87), eosinophils 20.2\% (normal: 0.8-4). Histological examination showed fat lobules composed of small lipocytes in the hyaline connective tissue. LIL is characterized bynon inflammatory focal loss of subcutaneous tissue [8].

\section{Conclusion}

In the last decade, several smaller studies were performed, demonstrating the positive effect of PRP on wound healing, the formation of granulation tissue and neo-vascularization $[4,6]$.

After activation, platelets synthetize and secrete a number of cytokines and growth factors, the most important ones being platelet-derived growth factor (PDGF), transforming growth factor beta-1 (TGF- $\beta 1$ ), vascular endothelial growth factor (VEGF) and epidermal growth factor (EGF). In one study, PRP and fat graft were used to dilate the gluteal augmentation [7].

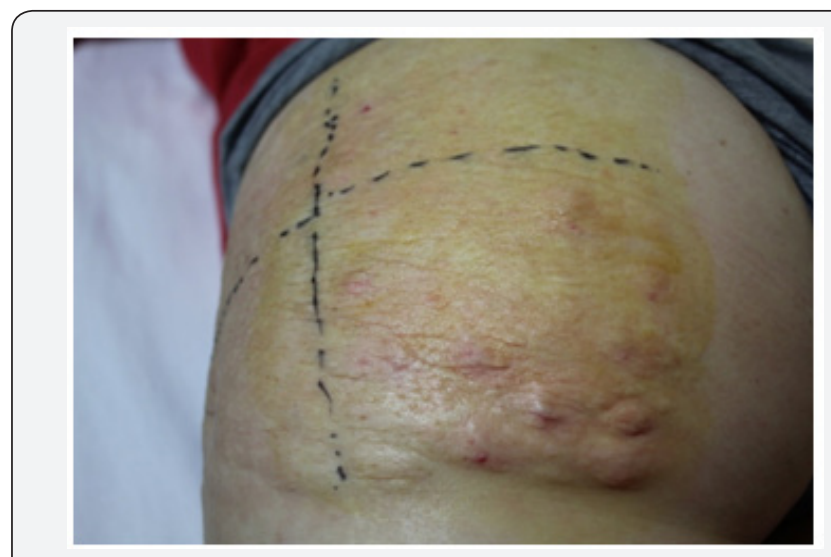

Figure 3: During treatment.
A total of 10 sessions PRP was administered every 2 weeks (Figure 3). The lesion was clinically resolved. Are peat biopsy was taken. Atrophy in the fatty tissue continued. Tissue loss was improved probably because PRP stimulated endothelial cells, fibroblasts, mesenchimal cells, smooth muscle cells for repairment (Figure 4). We treated depression in the gluteal region, not lipoatrophy, with PRP therapy. We didn't use a fat graft. We used only PRP.

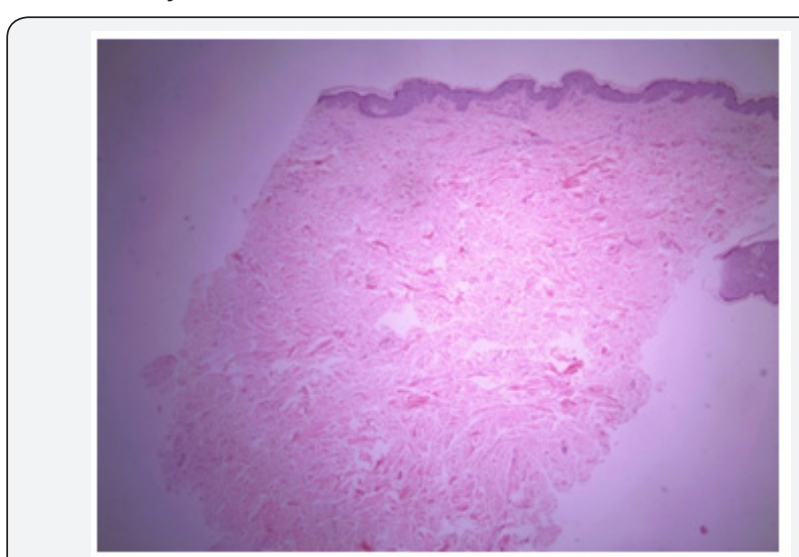

Figure 4: (HEX40) atrophic epidermis and increased collagen bundles in the dermis.

\section{References}

1. Dahl PR, Zalla MJ, Winkelmann RK (1996) Localized involutional lipoatrophy: A clinicopathologic study of 16 patients. J Am Acad Dermatol 35(4): 523-528.

2. Yamamoto T, Yokozeki H, Nishioka K (2002) Localized involutional lipoatrophy: report of sixcases. J Dermatol 29(10): 638-643.

3. Deng W, Boey J, Chen B, Byun S, Lew E, et al. (2016) Platelet-rich plasm abilayereda cellular matrix grafting and negative pressure wound therapy in diabetic foot infection. J wound Care 25(7): 393-397.

4. Leo MS, Kumar AS, Kirit R, Konathan R, Sivamani RK (2015) Systematic review of the use of platelet rich plasma in aesthetic dermatology. J Cosmet Dermatol 14(4): 315-323.

5. Yılmaz S, Aksoy E, Doğancı S, Yalçınkaya A, Diken AI, et al. (2015) Autologous platelet-rich plasma in treatment of chronic venous leg ulcers: A prospective case series. Vascular 23(6): 580-585.

6. Montero EC, Santos MEF, Fernandez RS (2015) Platelet-rich plasma: applications in dermatology. Actas Dermosifiliogr 106(2): 104-111.

7. Willemsen JC, Lindenblatt N, Stevens HP (2013) Results and longterm patient satisfaction after gluteal augmentation with platelet-rich plasma-enriched autologous fat. Eur J Plast Surg 36: 777-782.

8. Lee YB, Kim JU, Park HJ, Cho BK (2010) Two Cases of Idiopathic Localized Involutional Lipoatrophy. AnnDermatol 22(3): 346-348. 


Your next Submission with Juniper Publishers
will reach you the below assets
- Quality Editorial service
- Swift Peer Review
- Reprints availability
- E-prints Service
- Manuscript Podcast for convenient understanding
- Global attainment for your research
- Manuscript accessibility in different formats
( Pdf, E-pub, Full Text, Audio)
- Unceasing customer service
Track the below URL for one-step submission
https://juniperpublishers.com/online-submission.php

